\title{
Web Scraping and Winnowing Algorithms for Plagiarism Detection of Final Project Titles
}

\author{
Neng Ika Kurniati ${ }^{\mathrm{a} 1}$, Alam Rahmatulloh ${ }^{\mathrm{a} 2}$, Ridwan Nur Qomar ${ }^{\mathrm{a} 3}$ \\ ${ }^{a}$ Program Studi Informatika, Fakultas Teknik, Universitas Siliwangi \\ Siliwangi Street Number 24, Tasikmalaya City 46115, West Java, Indonesia \\ 1nengikakurniati@unsil.ac.id, ${ }^{2}$ alam@unsil.ac.id, ${ }^{3}$ ridwan.nurqomar14@student.unsil.ac.id
}

\begin{abstract}
Plagiarism in research can occur due to accident or intentional. Plagiarism is an act that violates copyright and includes actions that harm others. In submitting the title of the research, for example, for the final assignment research, not a few students who repeatedly submitted titles were rejected and considered doing plagiarism because the title proposed had already existed before. Then we need a system that can detect the similarity between the titles to be submitted and the existing titles so that it is expected to reduce the occurrence of plagiarism. This study uses a winnowing algorithm to find the percentage similarity between titles. The Google Scholar will be used to obtain data on research titles that have been previously available as comparison titles. Web scraping with CURL (Client URLs) and simple HTML DOM parser is used to retrieve title data from Google Scholar. The results of the study with the application of a Winnowing algorithm to find the percentage similarity to data from Google Scholar were able to present a percentage of similarities in percent with the category of mild, moderate or severe plagiarism, while also helping early detection as prevention of plagiarism.
\end{abstract}

Keywords: Final Project, Google Scholar, Plagiarism, Web Scraping, Winnowing Algorithm

\section{Introduction}

Determination of whether or not a title of the Final Project is acceptable and to find out whether the title already exists or not currently done is through control and selection of the lecturers or supervisors. Sometimes the ability of the lecturer in exercising control and selection is still constrained by having to check and find out with the memory abilities of each lecturer or supervisor that may be limited so that sometimes some titles pass the observation that causes duplicate titles.

Title duplication is a common form of plagiarism in writing final project [1], [2], [3]. As one way to overcome these problems, a system is needed to find out how much the percentage of the title of the research submitted by students with the title of the research that already exists. Data from research titles that have been available on Google Scholar, which include online journals from scientific publications [4] can be used to assist in obtaining other pre-existing titles as a reference or similar titles.

The application of web scraping with CURL (Client URLs) and simple HTML DOM parser can help to retrieve title data, as a comparison of existing research title data in google scholar [5]. Web scraping is a technique for retrieving information from a website [6], [7]. CURL is useful to transfer data to and from the server with a library and command line. CURL is useful for data retrieval methods from sites [8], [9]. Simple HTML DOM parser helps manipulate HTML elements that can work with HTML code that does not include W3C validation because Simple HTML DOM parsers are not limited to valid HTML classes. DOM elements can also be deleted, added, or changed. In HTML DOM data retrieval is based on tags, classes, IDs, and so on [10], [11]. 
Winnowing algorithm can be used to find the percentage of the similarity of the text of the research title proposed with the research title data from Google Scholar. Google Scholar is one of the references for search engine scientific publications so that data from the Google Scholar is a proper scientific work data used as a comparison in detecting the proposed title of the final assignment of student research.

The winnowing algorithm has fulfilled the prerequisites of the text similarity detection algorithm, namely whitespace insensitivity, i.e., only characters in the form of letters or numbers will be processed further and discard all irrelevant characters such as punctuation, spaces and other characters [12], [13]. The winnowing algorithm can detect plagiarism of text or documents even though the document has been changed in sentence structure either by spinning or paraphrasing techniques [14]. Compared to the Rabin-Karp algorithm, the winnowing algorithm produces a better percentage level with a faster processing time [15]. Previous research [16], [17], [18], [19], [20] has been carried out, but each study has not collaborated and utilized Google Scholar resources, as comparable data for the Final Project title using the Winnowing Algorithm.

Based on these problems, to reduce plagiarism and detect early submission of student research titles, a study was conducted entitled "Web Scraping and Winnowing Algorithms for Plagiarism Detection of Final Project Titles".

\section{Research Methods}

\subsection{Related Works}

Table 1 Research related to web scraping, winnowing algorithms, and google scholar include:

1. This study built a system to collect parallel corpus between Indonesian and English. The scraping process with the HTML DOM method has produced parallel corpus documents of 38,712 pairs [17].

2. This research builds a system to detect thesis titles using a winnowing algorithm to facilitate the final task coordinator or Chair of the Study Program in determining the percentage of similarities. The system in this study will detect the similarity of a title entered with the title data that has been stored in the database [18].

3. This research builds a website that is useful for finding the desired collection of journals. This website was created to streamline the search for scientific journals in the Mendeley and google scholar by utilizing ParsCit citation extraction paper data [19].

4. This study discusses the use of google scholar, which makes it easier for final level students to find legitimate reference sources for thesis assignments. Google scholar also makes it easy for trial examiners to search for words or sentences plagiarized by students who copy other people's work [20].

Table 1. Comparison of Related Research

\begin{tabular}{lllll}
\hline No. & Research & Web Scraping & Winnowing Algorithm & Google Scholar \\
\hline 1. & {$[17]$} & Yes & No & No \\
2. & {$[18]$} & No & Yes & No \\
3. & {$[19]$} & No & No & Yes \\
4. & {$[20]$} & No & No & Yes \\
5. & Proposed Research & Yes & Yes & Yes \\
\hline
\end{tabular}




\subsection{Web Scraping Architecture from Google Scholar}

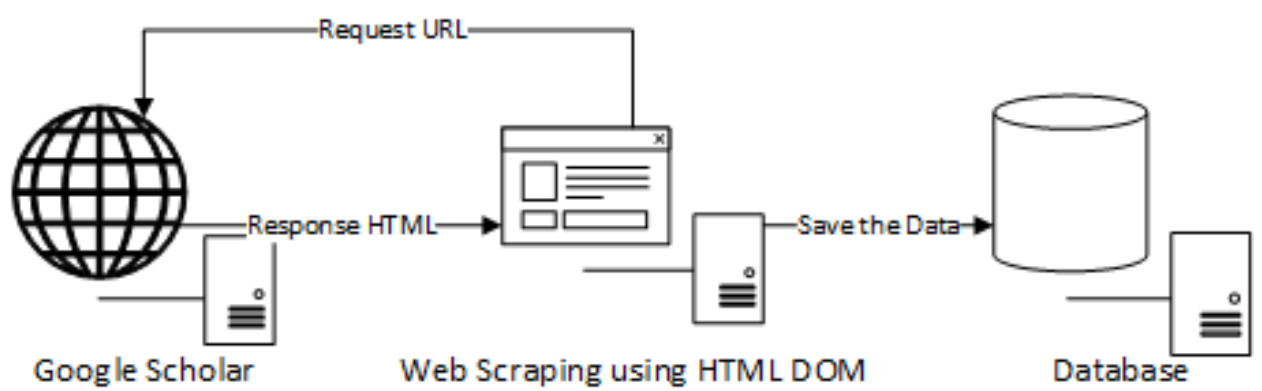

Figure 1. Web Scraping Architecture from Google Scholar

Figure 1 is a web scraping architecture. The web application requests Google Scholar, and then Google Scholar responds with HTML resources. Simple HTML DOM is used to convert HTML data and manipulate HTML elements for retrieving the data needed namely title data. Then the storage is carried out on the database, and the data is compared using a winnowing algorithm so that the comparison results with the value data in the form of a percentage of plagiarism.

\subsection{Flowchart of Plagiarism Detection using Web Scraping and Winnowing Algorithms}

Figure 2 a web scraping flowchart and winnowing algorithm. First, the user enters the title that will be checked by plagiarism, then the system with web scraping will retrieve the title data from the Google Scholar according to what was entered by the user. Next is the title data from Google Scholar compared to the similarity with the title entered by the user using the Winnowing algorithm. The last process of the system will display information on title data along with the percentage of similarity.

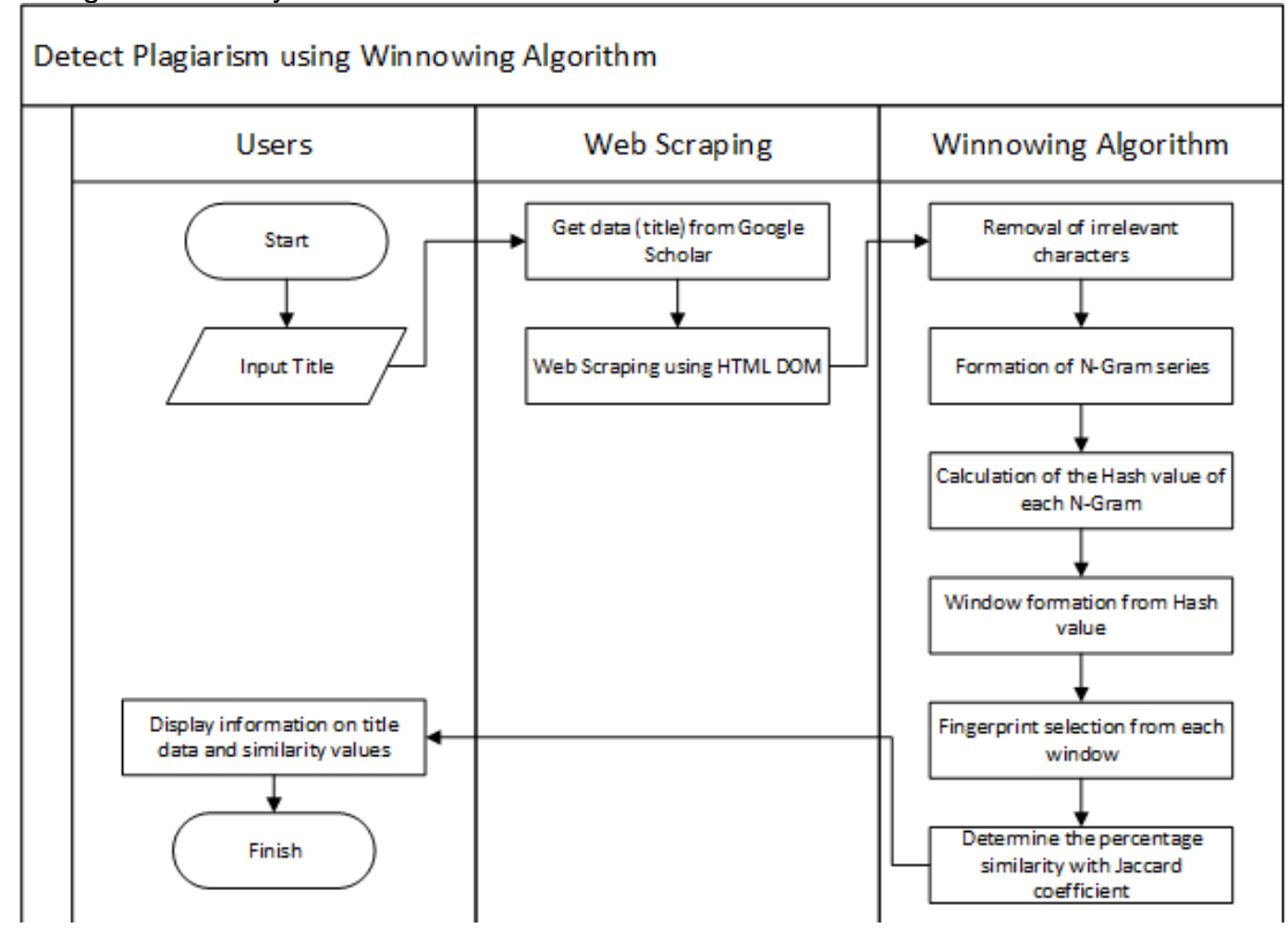

Figure 2. Flowchart of Plagiarism Detection using Web Scraping and Winnowing Algorithms 


\subsection{Textual Analysis}

This system is expected to help to reduce the occurrence of duplication of research titles or plagiarism. The user checks by entering the final project title. Furthermore, the system will retrieve title data with web scraping from Google Scholar according to the title entered by the user. The title data from Google Scholar will be processed with a winnowing algorithm to find the percentage similarity between the titles entered by the user and the title of the Google Scholar.

\subsection{Use Case}

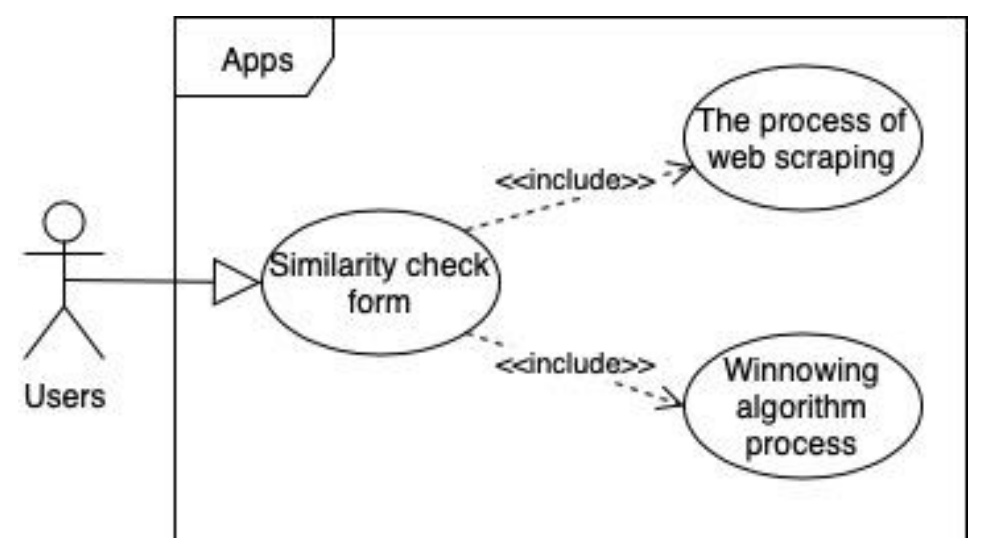

Figure 3. Use Case Diagram

The similarity check form in Figure 3 is a menu for checking the similarity of research titles with other research titles that already exist in Google Scholar by entering the research title to be searched for or checked for similarity. Web scraping is used to retrieve data from other research titles that already exist in Google Scholar as a reference or comparison. The process of finding the percentage similarity of the research title using the Winnowing algorithm by comparing the titles entered by the actor with the final project title data from Google Scholar. 


\subsection{Coding}

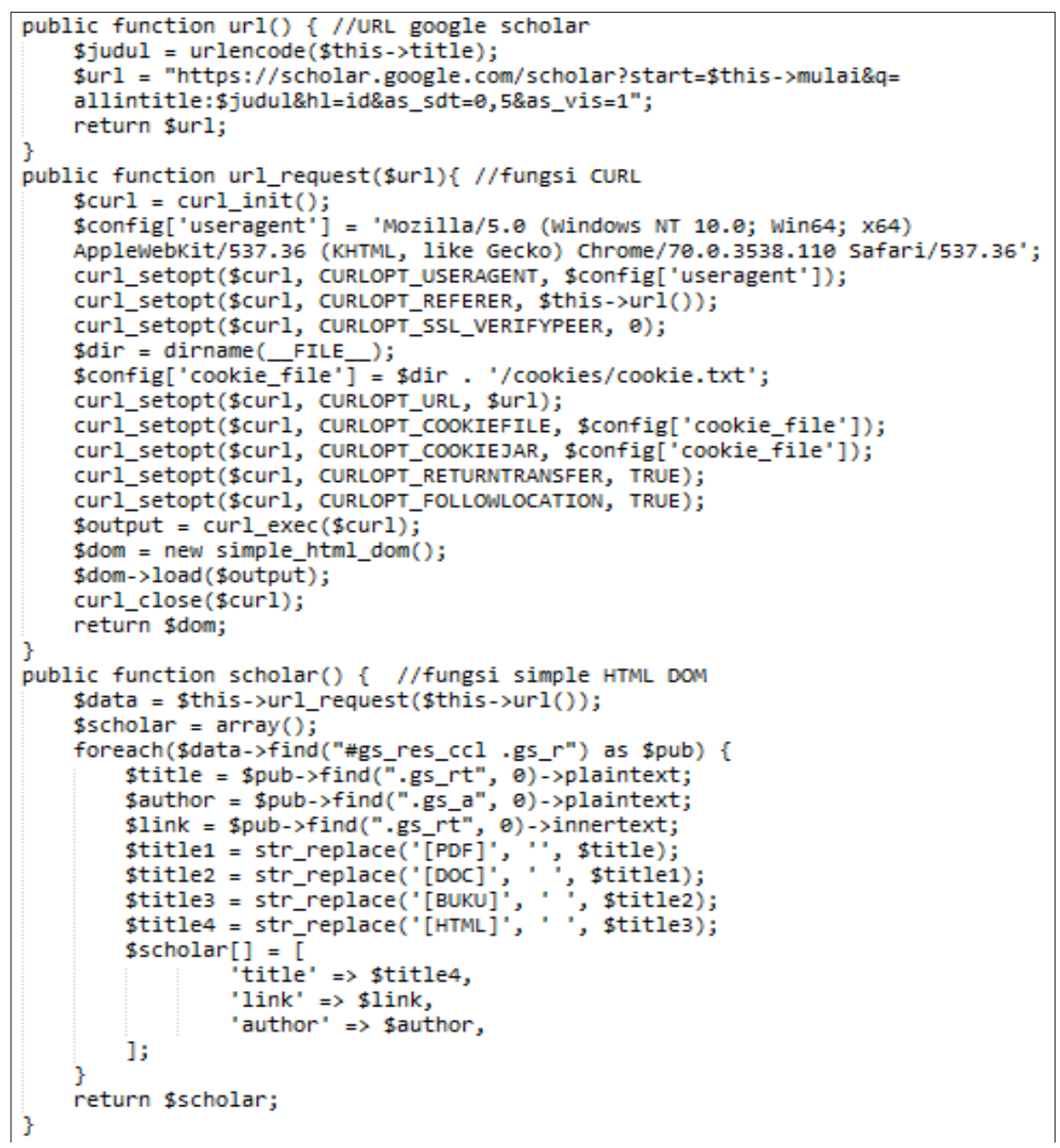

Figure 4. Source Code for Title Data Collection

Figure 4 is a code for web scraping programs using PHP to retrieve research title data from Google Scholar. Retrieving title data is per page with many titles, which are ten titles. Function url_request () is CURL which is used to send user agent information to Google Scholar like a web browser so that Google Scholar considers requests made by a user using a web browser and stores cookies given by Google Scholar. The function scholar () has a function to get the title data obtained by manipulating the Google scholar HTML data based on the id using the function of the simple HTML DOM parser library.

\section{Result and Discussion}

The user checks the similarity of the title by filling out the input form "enter the title". After filling in the title input form and pressing the search button, the system will display the research title data obtained from Google Scholar along with the percentage of similarities shown in Figure 5. 


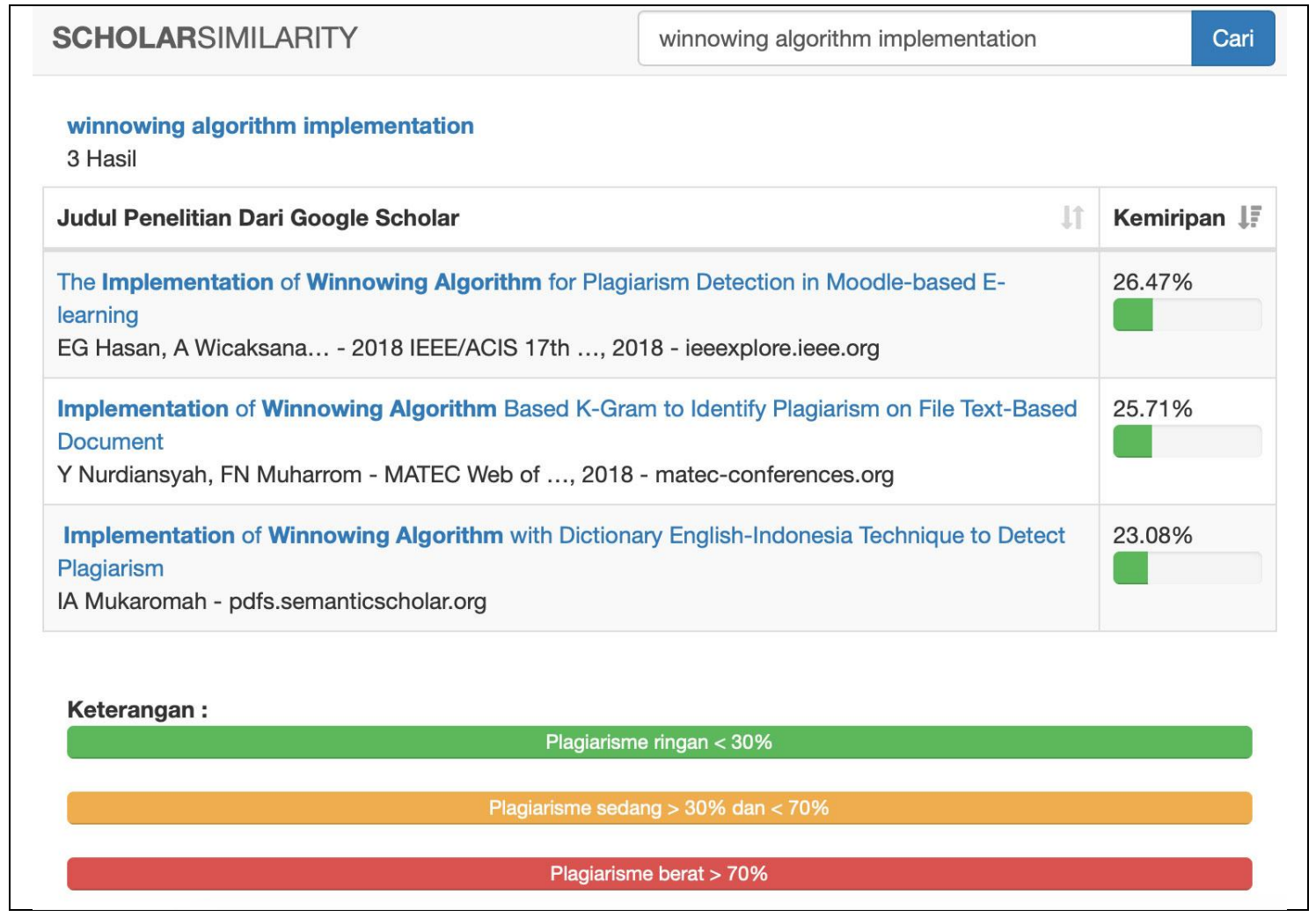

Figure 5. Display menu looking for title similarity

\subsection{Black-Box Testing}

Black-box testing is a method for testing software in terms of functional specifications without testing the design and program code. Testing is intended to find out whether the functions, inputs, and outputs of the software are by what is needed. Table 2 is the result of black-box testing in the application made

Table 2. Black Box Testing

$$
\text { Data Input }
$$

\section{Scenario}

Result

The title of the research to be sought

Will display the title data obtained from

Success Google Scholar along with the percentage of similarity

The title of the research to be searched Will not display the research title data Success is not available on Google Scholar including the percentage of similarity

\subsection{Testing the Winnowing Algorithm manually, using the system and tools plagiarism}

\subsubsection{Manual Testing}

The manual calculation is a calculation carried out directly by humans without using an application. The process of detecting the similarity of the first title "Implementasi Teknik Web Scraping Pada Aplikasi Pemesanan Tiket Kereta Api" to the second title "Implementasi Teknik Web Scraping Pada Aplikasi Pemesanan Tiket Pesawat".

a. Discard irrelevant characters and change all letters to lowercase in the first and second title text.

First title:

implementasiteknikwebscrapingpadaaplikasipemesanantiketkeretaapi 
Second title:

implementasiteknikwebscrapingpadaaplikasipemesanantiketpesawat

b. The formation of the $n$-gram circuit with $n=6$, it will form as follows:

n-gram first title:

\begin{abstract}
implem mpleme plemen lement ementa mentas entasi ntasit tasite asitek sitekn itekni teknik eknikw knikwe nikweb ikwebs kwebsc webscr ebscra bscrap scrapi crapin raping apingp pingpa ingpad ngpada gpadaa padaap adaapl daapli aaplik aplika plikas likasi ikasip kasipe asipem sipeme ipemes pemesa emesan mesana esanan sanant ananti nantik antike ntiket tiketk iketke ketker etkere tkeret kereta eretaa retaap etaapi
\end{abstract}

$n$-gram second title:

implem mpleme plemen lement ementa mentas entasi ntasit tasite asitek sitekn itekni teknik eknikw knikwe nikweb ikwebs kwebsc webscr ebscra bscrap scrapi crapin raping apingp pingpa ingpad ngpada gpadaa padaap adaapl daapli aaplik aplika plikas likasi ikasip kasipe asipem sipeme ipemes pemesa emesan mesana esanan sanant ananti nantik antike ntiket tiketp iketpe ketpes etpesa tpesaw pesawa esawat

c. Calculates the hash value in the first $n$-gram series "impleme", base value $(b)=3$, and $n$ gram circuit length $(n)=6$.

$$
\begin{gathered}
H_{(\mathrm{implem})}=\operatorname{ascii}(i) * 3^{5}+\operatorname{ascii}(m) * 3^{4}+\operatorname{ascii}(p) * 3^{3}+\operatorname{ascii}(l) * 3^{2}+\operatorname{ascii}(e) \\
* 3^{1}+\operatorname{ascii}(m) \\
H_{(\mathrm{implem})}=105 * 243+109 * 81+112 * 27+108 * 9+101 * 3+109 \\
\quad H_{(\mathrm{implem})}=38752
\end{gathered}
$$

The results of all calculations of the first title hash value are:

38752398124008538723375343908837908402114054437175409223903640670 37565391673959638713396934119036916372314035637343399613688940051 38605393673800839049356073621335846369224016838961382633834537141 40811387133969137535390733786840091365433902336980403434094638375 38694381804102738614379364029137872

The results of all calculations of the second title hash value are:

387523981240085387233753439088379084021140544371754092239036 406703756539167395963871339693411903691637231403563734339961 368894005138605393673800839049356073621335846369224016838961 382633834537141408113871339691375353907337868400913654339023 369804034340951383903874038314414323982937955

d. Setting a window with $w=4$.

Window first title:

W-1 : \{38752 398124008538723$\}$

$W-2:\{39812400853872337534\}$

$W-3:\{40085387233753439088\}$

..

W-56 : \{38614 379364029137872$\}$

Window second title:

$W-1:\{38752398124008538723\}$

$W-2:\{39812400853872337534\}$ 


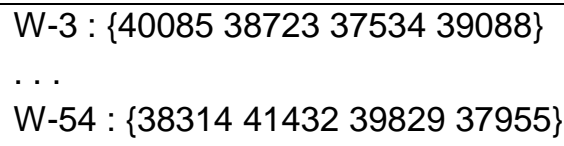

e. The selection of fingerprint values from the window formation.

fingerprint first title:

387233753437908371753756538713369163723136889380083560735846 36922382633714137535365433698038375381803793637872

fingerprint second title:

387233753437908371753756538713369163723136889380083560735846 369223826337141375353654336980383903831437955

f. Jaccard coefficient:

The same fingerprint from the first title and the second title:

(38723 3753437908371753756538713369163723136889380083560735846 $369223826337141375353654336980)=18$

The entire fingerprint is first and second title:

(38723 3753437908371753756538713369163723136889380083560735846 369223826337141375353654336980383753839038180383143793637955 $37872)=25$

Similarity :

Similarity $=\frac{18}{25} \times 100=72 \%$

Percentage of text similarity between first title and second title based on the results of the similarity of the two fingerprints with a manual calculation of $72 \%$.

\subsubsection{Calculations on the system}

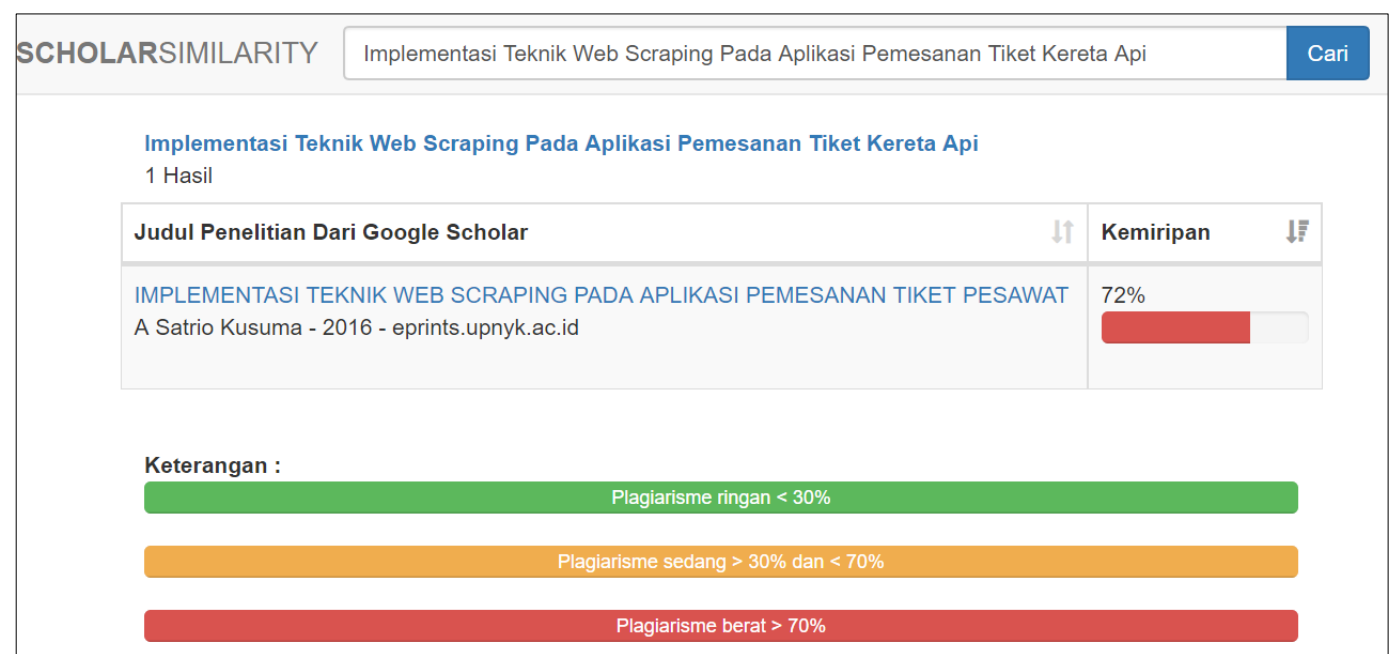

Figure 6. The results of the calculation of the winnowing algorithm on the system

Figure 6 shows the results of the calculation of the system winnowing algorithm with a value of $n$ $=6, \mathrm{w}=4$, and $\mathrm{b}=3$, with the results of $72 \%$ similarity.

These results indicate that the calculation of the manual winnowing algorithm and the system get the same results, namely $72 \%$. Plagiarism can be grouped according to proportion or percentage of sentences or hijacked paragraphs, namely mild plagiarism $(<30 \%)$, moderate plagiarism (30-70\%) and severe plagiarism (> 70\%) [21] [22]. 


\subsection{Testing with Plagiarism Checker $\mathbf{X}$ Tools}

This test was conducted to compare the results of the percentage similarity between the systems proposed in this study with tools plagiarism checker X.Plagiarism Checker $\mathrm{X}$ is a tool to help detect plagiarism in research papers, blogs, assignments, and websites. To find the percentage of the title similarity to the $X$ checker plagiarism application is done by side by side comparisons by entering the tested title and the comparison title.

Table 3. The title tested and the comparison title

\begin{tabular}{|c|c|c|}
\hline \multirow{3}{*}{$\frac{\text { No }}{1 .}$} & Tested Title & Comparative Title \\
\hline & Implementation of Web & Implementation of Web \\
\hline & $\begin{array}{l}\text { Techniques on Train Ticket Booking } \\
\text { Applications }\end{array}$ & $\begin{array}{l}\text { Techniques in Airplane Ticket Booking } \\
\text { Applications }\end{array}$ \\
\hline 2. & $\begin{array}{l}\text { Implementation of RESTful Web Service } \\
\text { for Election Vote Calculation System }\end{array}$ & $\begin{array}{l}\text { Implementation of RESTful Web Service } \\
\text { for Rapid Vote Counting System in Local } \\
\text { Election }\end{array}$ \\
\hline 3. & $\begin{array}{l}\text { CRM Implementation to Increase Customer } \\
\text { Loyalty }\end{array}$ & $\begin{array}{l}\text { Analysis of Electronic CRM Implementation } \\
\text { at PT Cordova Garment to Increase } \\
\text { Customer Loyalty }\end{array}$ \\
\hline 4. & $\begin{array}{l}\text { Medical Record Information System at } \\
\text { RSUD Pacitan General Hospital Based on } \\
\text { Android }\end{array}$ & $\begin{array}{l}\text { Medical Record Information System at the } \\
\text { Regional General Hospital of RSUD } \\
\text { Pacitan Based on Web Base }\end{array}$ \\
\hline 5. & $\begin{array}{l}\text { Similarity Thesis Detection System using } \\
\text { Rabin Karp's Algorithm }\end{array}$ & $\begin{array}{l}\text { Thesis Title Similarity Detection System } \\
\text { Using Winnowing Algorithms }\end{array}$ \\
\hline 6. & $\begin{array}{l}\text { Scientific Article Search Website by } \\
\text { Utilizing Google Scholar and Mendeley API }\end{array}$ & $\begin{array}{l}\text { Website Search for Scientific Articles by } \\
\text { Utilizing Parscit's Google Scholar and } \\
\text { Mendeley API }\end{array}$ \\
\hline 7. & $\begin{array}{l}\text { Web Scraping Implementation on } \\
\text { Ontology-Based Web for Drug Data }\end{array}$ & $\begin{array}{l}\text { Web Scraping Implementation on } \\
\text { Ontology-Based Web for Drug Data and } \\
\text { Disease }\end{array}$ \\
\hline 8. & $\begin{array}{l}\text { Implementation of Customer Relationship } \\
\text { Management in the Hotel Reservation } \\
\text { System }\end{array}$ & $\begin{array}{l}\text { Implementation of Customer Relationship } \\
\text { Management CRM in a Website and } \\
\text { Desktop-based Hotel Reservation System }\end{array}$ \\
\hline 9. & $\begin{array}{lccc}\begin{array}{l}\text { Designing } \\
\text { competitive }\end{array} & \text { Information } & \text { Systems for } \\
\text { companies } & & \text { of } & \text { modern } \\
\text { complanes } & & \end{array}$ & $\begin{array}{l}\text { Analysis and Design of Information } \\
\text { Systems for competitive advantages of } \\
\text { modern companies and organizations }\end{array}$ \\
\hline 0 . & $\begin{array}{l}\text { Information System Distribution of } \\
\text { Information Technology Research Sites in } \\
\text { Garut }\end{array}$ & $\begin{array}{l}\text { Designing Geographic Information } \\
\text { Systems Distribution of Information } \\
\text { Technology Research Sites in the City of } \\
\text { Garut }\end{array}$ \\
\hline e. & $\begin{array}{l}\text { signing Achievement Decision Selection } \\
\text { stem for Student Achievement }\end{array}$ & $\begin{array}{l}\text { ning the Decision Support System for } \\
\text { selection of Outstanding Students } \\
\text { the AHP and Promethee Methods }\end{array}$ \\
\hline
\end{tabular}

Table 3 is the title data tested and the title data as a comparison so that the percentage value of plagiarism will be obtained using the system proposed in the study with tools plagiarism checker $\mathrm{X}$.

Table 4. Similarity percentage comparison

\begin{tabular}{ccc}
\hline No. & This Research & Plagiarism Checker X tools \\
\hline 1. & $72 \%$ & $89 \%$ \\
2. & $68.75 \%$ & $67 \%$ \\
3. & $38.89 \%$ & $0 \%$ \\
4. & $80.65 \%$ & $86 \%$ \\
5. & $70.37 \%$ & $88 \%$ \\
6. & $87.5 \%$ & $92 \%$ \\
7. & $83.87 \%$ & $85 \%$ \\
8. & $58.97 \%$ & $62 \%$ \\
9. & $54.29 \%$ & $58 \%$
\end{tabular}


10.

11.

Average
$46.47 \%$

$67.57 \%$

$66.30 \%$
$46 \%$

$62 \%$

$66.82 \%$

Table 4 is the percentage data of the plagiarism value from the comparison between the systems proposed in the study with tools plagiarism checker X. The system created has a smaller percentage average of $66.30 \%$ compared to $X$ plagiarism checker application, with an average of $66.82 \%$.

\section{Conclusion}

Based on the results of testing in the study conclusions can be drawn, namely; Web scraping with CURL and simple HTML DOM parser can be applied to retrieve data from Google Scholar's research title on early detection applications for submitting student research titles. Google Scholar can be used to obtain other existing research titles as a reference or comparison in early detection applications submitting student research titles by applying web scraping as a method of retrieving data. Winnowing algorithm can be applied to find the percentage similarity of the research title proposed with the existing research title in Google Scholar in the application of early detection submission of student research titles. This research is still lacking. Namely, the comparative title data source only from Google Scholar and the data compared only to the title, can not know the author of the scientific work. Also, the application of the method in this study has not been able to detect research titles with different languages.

\section{References}

[1] N. Knock dan R. Davison, "Dealing with Plagiarism in the Information Systems," MIS Quarterly, vol. 27, pp. 511-532, 2003.

[2] Mulyana, "Pencegahan Tindak Plagiarisme Dalam Penulisan Skripsi," Cakrawala Pendidikan, 2010.

[3] A. Y. Gasparyan, B. Nurmashev, B. Seksenbayev, V. I. Trukhachev, E. I. Kostyukova dan G. D. Kitas, "Plagiarism in the Context of Education and Evolving Detection Strategies," Journal of Korean Medical Science, vol. 32, no. 8, pp. 1220-1227, 2017.

[4] Google, "Tentang Google Cendikia," [Online]. Available: https://scholar.google.com/int//id/scholar/ about.html. [Diakses 9 September 2018].

[5] R. Gunawan, A. Rahmatulloh, I. Darmawan dan F. Firdaus, "Comparison of Web Scraping Techniques: Regular Expression, HTML DOM and Xpath," dalam 2018 International Conference on Industrial Enterprise and System Engineering (ICOIESE 2018), Atlantis Press, 2019.

[6] B. G. Dastidar, D. Banerjee dan S. Sengupta, "An Intelligent Survey of Personalized Information Retrieval using Web Scraper," International Journal of Education and Management Engineering, vol. 5, no. 3, pp. 24-31, 2016.

[7] M. Turland, "php| architect's Guide to Web Scraping with PHP," Marco Tab ini\&Associates, 2010.

[8] D. Stenberg, "CURL: curl groks URLs," 2015.

[9] M. I. Khalid, PHP/CURL Book with Examples Version 1.8, 2006.

[10] V. B. Kadam dan G. K. Pakle, "A Survey on HTML Structure Aware and Tree Based Web Data Scraping Technique," International Journal of Computer Science and Information Technologies (IJCSIT), vol. 5, no. 2, pp. 1655-1658, 2014.

[11] V. Janjic, "PHP Simple HTML DOM Parser: Editing HTML Elements in PHP," 7 September 2011. [Online]. Available: https://phpbuilder.com/php-simple-html-dom-parser-editing-htmlelements-in-php/. [Diakses 6 Oktober 2018].

[12] X. Duan, M. Wang dan J. Mu, "A Plagiarism Detection Algorithm based on Extended Winnowing," dalam 2017 International Conference on Electronic Information Technology and Computer Engineering (EITCE 2017), 2017. 
[13] S. Schleimer, D. S. Wilkerson dan A. Aiken, "Winnowing: Local Algorithms for Document Fingerprinting," Proceedings of the ACM SIGMOD international conference on management of data, pp. 76-85, 2003.

[14] H. Tri Nugroho I, "Pengaruh Algoritma Stemming Nazief-Adriani Terhadap Kinerja Algoritma Winnowing Untuk Mendeteksi Plagiarisme Bahasa Indonesia," ULTIMA Computing, vol.9, no. 1, pp. 36-40, 2017.

[15] N. Alamsyah, "Perbandingan Algoritma Winnowing dengan Algoritma Rabin Karp untuk Mendeteksi Plagiarisme pada Kemiripan Teks Judul Skripsi," Technologia, vol. 8, no. 3, pp. 124-134, 2017.

[16] I. P. A. Darmawan dan I. N. P. I. P. A. Dharmaadi, "Ekstrak Hirarki Data Dari Situs Web A-Z Animals Menggunakan Web Scraping," Lontar Komputer : Jurnal Ilmiah Teknologi Informasi, vol. 8, no. 3, pp. 124-134, 2017.

[17] V. Mitra, H. Sujaini dan A. B. Putra Negara, "Rancang Bangun Aplikasi Web Scraping Untuk Korpus Paralel Indonesia - Inggris Dengan Metode HTML DOM," Jurnal Sistem dan Teknologi Informasi (JUSTIN), vol. 5, no. 1, pp. 36-41, 2017.

[18] Nurdin dan A. Munthoha, "Sistem Pendeteksi Kemiripan Judul Skripsi Menggunakan Algoritma Winnowing," InfoTekJar (Jurnal Nasional Informatika dan Teknologi Jaringan), vol. 2, no. 1, pp. 90-97, 2017.

[19] I. Ruslan, A. Wibowo dan R. Lim, "Website Penelusuran Artikel Ilmiah dengan Memanfaatkan Parscit, Google Scholar, dan Mendeley Api," Jurnal Infra, vol. 1, no. 2, 2013.

[20] K. Tiara, U. Rahardja dan I. A. Rosalinda, "Pemanfaatan Google Scholar Dan Citation Dalam Memenuhi Kebutuhan Pembuatan Skripsi Mahasiswa Pada Perguruan Tinggi," Technomedia Journal (TMJ), vol. 1, no. 1, pp.95113, 2016.

[21] S. Sastroasmoro, "Beberapa Catatan tentang Plagiarisme," Majalah Kedokteran Indonesia, vol. 57, no. 8, Agustus, 2007.

[22] J. D. Velásquez dan E. M. Taylor, "Tools for External Plagiarism Detection in DOCODE," dalam WI-IAT '14 Proceedings of the 2014 IEEE/WIC/ACM International Joint Conferences on Web Intelligence (WI) and Intelligent Agent Technologies (IAT), 2014. 